\title{
Towards adaptive fire management for biodiversity conservation: Experience in South African National Parks
}

\author{
Authors: \\ Brian W. van Wilgen ${ }^{1}$ \\ Navashni Govender ${ }^{2}$ \\ Gregory G. Forsyth ${ }^{1}$ \\ Tineke Kraaij ${ }^{3}$ \\ Affiliations: \\ ${ }^{1}$ Centre for Invasion \\ Biology, CSIR Natural \\ Resources and the \\ Environment, Stellenbosch, \\ South Africa \\ ${ }^{2}$ Scientific Services, Kruger \\ National Park, Skukuza, \\ South Africa \\ ${ }^{3}$ Scientific Services, Garden \\ Route, South Africa \\ Correspondence to: \\ Brian van Wilgen \\ Email: \\ bvwilgen@csir.co.za \\ Postal address: \\ PO Box 320, Stellenbosch \\ 7599, South Africa \\ Dates: \\ Received: 03 Dec. 2009 \\ Accepted: 13 July 2010 \\ Published: 13 May 2011 \\ How to cite this article: \\ Van Wilgen, B.W., \\ Govender, N., Forsyth, G.G. \\ \& Kraaij, T., 2011, 'Towards \\ adaptive fire management \\ for biodiversity \\ conservation: Experience \\ in South African National \\ Parks', Koedoe 53(2), Art. \\ \#982, 9 pages. doi:10.4102/ \\ koedoe.v53i2.982
}

(c) 2011. The Authors Licensee: OpenJournals Publishing. This work is licensed under the Creative Commons Attribution License.
This paper reviews the experience gained in three South African national parks (Kruger, Table Mountain and Bontebok) with regard to the adaptive management of fire for the conservation of biodiversity. In the Kruger National Park, adaptive approaches have evolved over the past 15 years, beginning initially as a form of 'informed trial and error', but progressing towards active adaptive management in which landscape-scale, experimental burning treatments are being applied in order to learn. In the process, significant advances in understanding regarding the role and management of fire have been made. Attempts have been made to transfer the approaches developed in Kruger National Park to the other two national parks. However, little progress has been made to date, both because of a failure to provide an agreed context for the introduction of adaptive approaches, and because (in the case of Bontebok National Park) too little time has passed to be able to make an assessment. Fire management interventions, ultimately, will manifest themselves in terms of biodiversity outcomes, but definite links between fire interventions and biodiversity outcomes have yet to be made.

Conservation implications: Significant challenges face the managers of fire-prone and fire adapted ecosystems, where the attainment of ecosystem goals may require approaches (like encouraging high-intensity fires at hot and dry times of the year) that threaten societal goals related to safety. In addition, approaches to fire management have focused on encouraging particular fire patterns in the absence of a sound understanding of their ecological outcomes. Adaptive management offers a framework for addressing these issues, but will require higher levels of agreement, monitoring and assessment than have been the case to date.

\section{Introduction}

South African National Parks (SANParks) have a primary mandate to conserve, on the land that they manage, South Africa's biodiversity, landscapes and associated heritage assets. In line with this, broad conservation goals normally call for the maintenance of all elements of biodiversity over space and time (SANParks 2008). Managers of most national parks have used a range of interventions to achieve the goals of biodiversity conservation, but in recent years there has been a growing recognition that top-down, 'command-and-control' management can be both ineffective and damaging (Holling \& Meffe 1996). This, in turn, has led to the introduction of adaptive forms of management in national parks. Adaptive management was introduced into the Kruger National Park (KNP) in the early 1990s (Biggs \& Rogers 2003) and, as practised by SANParks, has the following key features (SANParks 2008):

- the development of a shared vision and desired state for the future of the park

- the formulation of a hierarchy of objectives, agreed to by all stakeholders, that will provide a defendable purpose and clear focus for management for achieving the desired state

- the formulation of targets (or thresholds of potential concern), with the help of experts, to describe the boundaries of the desired state that management aims to achieve

- the implementation of agreed management actions, and the monitoring of outcomes in terms of agreed targets or thresholds

- in cases where targets are not met, or thresholds are exceeded, that consideration be given to management interventions that will drive the system towards targets or thresholds, or, alternatively, targets or thresholds can be recalibrated.

The above may be regarded as 'passive adaptive management' (Wilhere 2002), which involves the formulation of predictive models, making policy decisions based on these models, and revising the models or the policy as monitoring data become available. Active adaptive management, on the other hand, deliberately applies different management approaches, as in an experiment with replication (Walters \& Green 1997; Wilhere 2002). Proponents of active adaptive management argue that it accelerates learning, which is required if sustainability goals are to be met in any 
reasonable timeframe. For example, the Resilience Alliance states that 'adaptive management seeks to aggressively use management intervention as a tool to strategically probe the functioning of an ecosystem' (Resilience Alliance 2010), both to change the system and to learn about the system.

Many of South Africa's national parks are fire-prone, and fire is an important process to consider when managing these ecosystems for biodiversity (Bond 1997). Managers therefore often seek to influence the timing, frequency, size and intensity of fires, and the evolution of fire management has a long history in South African ecology (Edwards 1984; Phillips 1930; Van Wilgen 2009a, 2009b). The KNP also has a long history of fire management (Joubert 2007), including a move to adaptive management of fire in the late 1990s (Van Wilgen, Biggs \& Potgieter 1998; Van Wilgen, Govender \& MacFadyen 2008). More recently, adaptive approaches to fire management have been proposed for two additional national parks (Table Mountain National Park [TMNP] and Bontebok National Park [BNP]), and there is potential to expand these approaches further to other fire-prone national parks.

This paper reviews the development and use of adaptive approaches to manage fire in the KNP, TMNP and BNP. It provides an assessment of the degree to which these approaches have impacted on the conservation of biodiversity, and discusses the ongoing challenges that will face managers when expanding these approaches to other national parks.

\section{Achieving management goals through the use of fire The goals of management}

For the purposes of this discussion on the use of fire, we have divided management goals in national parks into two broad categories. These are, (1) ecosystem goals, which include the conservation of biodiversity and landscapes and (2) societal goals, which include the impacts of fire on people, assets and infrastructure. In the case of national parks, societal goals include the protection of park assets and the safety of inhabitants and visitors, as well as infrastructure, crops and people outside of the park's borders. In the sections that follow, we provide a broad, but brief, background to the use of fire as a management tool to achieve a range of goals.

\section{The use of fire to achieve ecosystem goals}

Ecosystem managers often use fire as an intervention to influence vegetation structure and composition by manipulating the timing and frequency of fire. These interventions are normally based on an understanding of the ecology and responses of species and ecosystems to fire. Examples of such interventions include:

- the improvement of grazing for wildlife in grassland, savanna and fynbos ecosystems by burning to maintain the vigour and palatability of the grass sward (Bond 1997; Kraaij \& Novellie 2010)
- the maintenance of populations of long-lived, obligate reseeding shrubs (mainly in the family Proteaceae) in fynbos ecosystems. In this case, increases in fire frequency or shifts in fire season are detrimental, and managers seek to burn in appropriate seasons, and at appropriate intervals, to prevent population declines (Van Wilgen, Bond \& Richardson 1992)

- the prevention of increases in the density of woody plants in savannas ('bush encroachment'), brought about by the combined effects of historic reductions in fire frequency, overgrazing, reductions in browsing (especially where elephant populations have been reduced) and increases in atmospheric carbon dioxide (Bond, Woodward \& Midgley 2003; Kraaij \& Ward 2006; Roques, O'Connor \& Watkinson 2001). The usual approach here is to apply frequent fires of high intensity that would increase woody plant mortality and favour grasses

- the integration of fire with efforts to control invasive alien plants, especially where these are spread by fire. Pines and hakeas in fynbos, and Australian wattles in most fireprone ecosystems, are good examples (Holmes et al. 2000; Van Wilgen et al. 1992).

Despite the widespread use of fire to achieve specific ecosystem objectives, simple yet robust goals that can cater for the protection and maintenance of all aspects of biodiversity are not easily formulated. For this reason, managers sometimes express goals in terms of desired fire regimes. Fire regimes describe the patterns of fires in a particular ecosystem, and include the season, frequency, intensity, severity and size distribution of historical fires in the area concerned (Gill \& Allan 2008). Management goals can be expressed in terms of achieving target ranges of each of these elements, which are in turn delimited, based on an understanding of ecological responses to fire. Because there is little or no understanding of responses to fire for most species, the assumption is made that, by promoting a variable fire regime within agreed limits, the survival of such species will be ensured because the variation will capture the conditions under which the ecosystem had evolved historically, and to which its component species would be pre-adapted (Brockett, Biggs \& Van Wilgen 2001; Van Wilgen et al. 1998).

\section{Fire and the achievement of societal goals}

Managers of fire-prone protected areas, unless these areas are very large or sufficiently remote, have to contend with the effects of fires within a landscape that includes developed areas, crops or plantations, often immediately adjacent to the protected area. Achieving the goals of safety and the protection of assets in such landscapes often requires the application, prevention, suppression and containment of fire in ways that may not be optimal for biodiversity conservation. As a result, there are often serious conflicts of interest in fire management. For example, unplanned fires that would otherwise be regarded as beneficial, and even necessary, for the maintenance of healthy ecosystems, may pose serious threats and have to be suppressed or contained for safety reasons. In addition, prescribed burning at the height of the 
fire season (often the best time to burn for ecological reasons), or at the high intensities needed for reversing or containing bush encroachment, often cannot be carried out because of restrictions imposed from outside national parks (for example, by fire protection associations). Suppressing and containing unplanned fires is also expensive, as it involves the use of labour, vehicles, aircraft and other specialised equipment, and can deplete funds that may otherwise have been available for fire management to achieve conservation objectives. Burning to reduce fuel loads, and the preparation of firebreaks, are two additional approaches used to achieve safety goals, although they are not universally successful (Van Wilgen et al. 2010).

\section{Adaptive management and fire}

Various approaches to managing fires have been adopted, or proposed, to achieve the goals set by SANParks and managers of other protected areas. These include regular or flexible prescribed burning (Bands 1977; Edwards 1984), 'adaptive interference' (Van Wilgen, Richardson \& Seydack 1994), natural (lightning) fires (Biggs \& Potgieter 1999; Seydack, Becker \& Marshall 2007), patch mosaic burning (Brockett et al. 2001) and range condition burning (Biggs \& Potgieter 1999). None of these approaches are perfect, and each has shortcomings. Common problems include the following, (1) unplanned fires that disrupt prescribed burning plans, (2) suitable safe weather in which to burn is scarce, (3) complications arise as a result of the presence of invasive alien plants and (4) public resistance to deliberate burning. Furthermore, the long-term ecological outcomes of each approach cannot always be predicted accurately. The degree to which managers can influence long-term fire regimes in reality, and whether or not a significant degree of control is actually necessary, are two issues that need clarification. For example, recent reviews have revealed that managers have not exerted a significant degree of control over fire regimes, despite policies that promote prescribed burning with this aim in mind (Van Wilgen et al. 2004, 2010).

Adaptive fire management, as practised by or proposed for SANParks, has sought to address some of these issues. The approach has been to set targets in terms of elements of the fire regime, and to monitor whether the fire regimes that arise from various forms of management remain within the specified ranges. Initially this was carried out as an interim measure, until better information became available (Van Wilgen et al. 1998). The Resilience Alliance does not recognise this type of management as adaptive management, but rather as 'informed trial and error', where the best available knowledge is used to generate a 'risk-averse, best-guess' strategy, which can be changed when new information allows for the initial strategy to be modified (Resilience Alliance 2010). The sections that follow provide a brief history of the evolution of adaptive management approaches in SANParks.

\section{Study areas}

This assessment focused on the KNP, TMNP and BNP. Although the need to manage fires is common to all three of these parks, the parks differ in many other respects (Table 1). The parks differ in size by orders of magnitude, which impacts on the options available for fire management. The vegetation of the KNP is a well-wooded savanna, in which fires occur regularly during the dry winter at return intervals of about $2-4$ years. As a typical, semi-arid savanna, it displays wide levels of variability. The predominant vegetation of the TMNP comprises evergreen, mountain fynbos shrublands, with well-developed Afromontane forests occurring in sheltered areas. These forests tend to be fire-free, although forest margins are scorched by fire from time to time. The fire regime of the area is characterised by dry-season (summer) fires at intervals of between 10 and 20 years. The BNP is covered by a mixture of fynbos and renosterveld shrublands. The fire regimes of these lowland areas are not well documented, but fire return intervals are thought to be shorter than those typical of mountain fynbos areas. Importantly, a different set of issues exists in each area, which complicates or constrains fire management in different ways.

\section{Adaptive fire management in the Kruger National Park} Early development of adaptive fire management

Fire management policies in the KNP have changed several times over the past century, and have included fire protection and suppression, various forms of deliberate prescribed burning on fixed areas, the promotion of a lightning-driven fire regime, and point-ignition patch burning. These changes are well documented (Biggs and Potgieter 1999; Joubert 2007; Van Wilgen et al. 2004, 2008, 2010; Venter et al. 2008) and are not repeated in detail here. The development of fire management has also been informed by long-term and ongoing fire research (Brynard 1971; Van der Schijff 1958; Van Wilgen, Govender \& Biggs 2007).

Considerable changes in fire management came about, following the adoption of a heterogeneity paradigm in the

TABLE 1: Salient features of three national parks to which adaptive approaches to fire management have been introduced.

\begin{tabular}{|c|c|c|c|}
\hline National Park & Area (ha) & Dominant vegetation & Issues that impact on fire management options \\
\hline Kruger & 1948528 & Savanna woodlands & $\begin{array}{l}\text { - Interactions between herbivores (especially elephants) and fire. } \\
\text { - } \quad \text { Bush encroachment. }\end{array}$ \\
\hline Table Mountain & 26553 & Fynbos shrublands and forest patches & $\begin{array}{l}\text { - Close proximity to urban areas (resistance to burning and threats to safety). } \\
\text { - Infestations of fire-adapted, invasive, alien trees. }\end{array}$ \\
\hline Bontebok & 3435 & Fynbos and renosterveld shrublands & $\begin{array}{l}\text { - The need to burn to provide grazing for bontebok, while at the same time conserving fire- } \\
\text { sensitive, rare flora. }\end{array}$ \\
\hline
\end{tabular}


early 1990s, with variability as a central concept (Mentis \& Bailey 1990; Rogers 2003). This new thinking coincided with the introduction of adaptive management in the KNP (Biggs \& Rogers 2003) and in 1998, led to a set of objectives relating to fire management, embedded in the hierarchy of objectives, and the formulation of fire-specific thresholds of potential concern (Van Wilgen et al. 1998). In this hierarchy, the KNP's overall goal of maintaining biodiversity in all its natural facets and fluxes would be supported by the development of an understanding of the role of fire as an ecosystem process. Specific objectives included research to understand the effects of point versus perimeter-ignited burns, the effects of spatial heterogeneity in fires, the effects of fire on vegetation structure and on animals, and historic fire patterns. Ultimately, the goal was to use this understanding to develop an informed context for fire management.

The original fire-related thresholds (formulated in 1998) included addressing the cause of fires. This was included to ensure that most fires originated from lightning. While the cause of fires has little biological significance, it was argued that, in order to effectively promote a 'natural' (lightningdriven) fire regime, most fires would need to be ignited by lightning. As it turned out, most fires were not started by lightning. The management approach was then changed to one that combined point ignitions ('patch fires', Brockett et al. 2001) with unplanned and lightning fires. The approach aimed to burn an annual target area, determined by rainfall and fuel conditions, in point-ignition fires of different sizes. The number of fire-related thresholds was reduced from seven to two (Van Wilgen et al. 2008). These were, (1) a threshold that would be reached if the area covered by fires in any one of three intensity classes (very low and low combined, moderate, and high and very high combined) constituted $<20 \%$ or $>50 \%$ of total area burnt in a given year and (2) a threshold that would be reached if a heterogeneity score (which measured the spatial heterogeneity of fire patterns) dropped below a predetermined value for two consecutive years.

\section{Gaining new understanding}

The process of formulating, evaluating and reformulating thresholds for fire management has resulted in several advances in our understanding. As a result, managers now have a more informed context for fire management. Advances in understanding include:

- the demonstration that the area burnt in any given year is driven by variation in annual rainfall, and is largely unaffected by attempts to impose an annual burning target through prescribed burning (Van Wilgen et al. 2004)

- the further demonstration that, although fire management does not influence the total area burnt, it is able to influence both the spatial heterogeneity and seasonal distribution of areas burnt through prescribed burning (Van Wilgen et al. 2004)

- the conclusion, from burning on experimental plots, that the KNP's savannas are remarkably resilient under a wide range of fire treatments, and that fire has few negative effects unless the fire regimes deviate markedly from the norm (these deviations included burning every year, burning in the wet summer season, or long periods of fire exclusion (Van Wilgen et al. 2007)

- the demonstration of the importance of fire intensity (as opposed to season or return period) for determining the survival rate of wood plants after fire, and the balance between grasses and trees (Higgins, Bond \& Trollope 2000; Trollope 1998).

\section{Moving from passive to active adaptive management}

In response to this understanding, the focus of fire management has shifted from attempts to control return periods and seasons to influencing spatial heterogeneity in fire intensity. New thresholds have been formulated, and a threshold for area burnt in high-intensity fires (as opposed to moderate or low-intensity fires) has been exceeded more than once, suggesting a need to find a way to reduce the proportion of high-intensity fires. A landscape-scale experiment has been initiated to establish the effects of ignition patterns (point ignitions or perimeter ignitions) on the proportion of area that burns at different intensities. The hypothesis is that point ignitions will generate a greater diversity of fire intensities within a single management fire, as it is thought that most of the area burnt in a perimeter-ignited fire burns as a high-intensity headfire. The contrasting of perimeter and point ignitions is of particular interest to managers, who favour the perimeter ignitions, as they allow for more control of fire. In order to persuade managers to replace a perimeterignition system with one of point ignitions, it will be necessary for researchers to demonstrate that, (1) different ignition patterns will result in differences in patterns of fire intensity and (2) these differences in fire intensity are meaningful in terms of biodiversity outcomes. This short history suggests that the use of fire initially followed the 'informed trial and error' approach, but that, with the initiation of the landscapescale experiment, it has entered a phase of active adaptive management in which large-scale treatments are applied across the landscape in order to learn.

\section{Remaining issues}

Despite many advances in the understanding of the role and management of fire and a recognition that fire, as an ecological driver of vegetation composition and structure, is perhaps not as important as was once thought (Van Wilgen \& Biggs 2010), the need for ongoing development of further understanding is frequently expressed. It is recognised as simplistic to treat the entire KNP (approximately 2 million ha) as homogenous, and to apply a single set of fire-related thresholds over the entire area. Mean annual rainfall varies from between approximately $350 \mathrm{~mm}$ in the north and approximately $750 \mathrm{~mm}$ in the south, and the effects of fire are far more marked in areas of higher rainfall (Van Wilgen et al. 2007). In addition, important differences in responses to fire are apparent on the two major geological substrates (granite and basalt), suggesting that at least four sets of targets or thresholds (low and high rainfall on granite and 
basalt, respectively) would be more appropriate, but these have yet to be developed.

The interactions between elephants and fire are also not clearly understood, but are important. Concern is often expressed about declining numbers of large trees in the KNP, which is partly due to interactions between fire and herbivory by elephants (Eckhardt, Van Wilgen \& Biggs 2000; Edkins et al. 2007). Where, whether, and how managers should intervene in this regard remains unclear. Furthermore, rising levels of carbon dioxide in the atmosphere will favour trees over grasses (Bond et al. 2003). Managers may wish to counter the expected increases in woody plant density if losses of biodiversity are to be avoided. This, in turn, may require the application of high-intensity and possibly, dangerous, fires to control woody plant growth (Bond \& Archibald 2003), and is likely to present significant challenges to managers.

\section{Expanding adaptive fire management to other national parks Table Mountain National Park}

In 2000 a fire management plan was prepared, on contract, for the TMNP (Forsyth et al. 2000), and revised in 2004 (Forsyth \& Bridgett 2004) by the Council for Scientific and Industrial Research (CSIR). Then, in 2007 the park requested the CSIR to formulate a set of fire-associated thresholds for assessing the condition of the park's fire-dependant ecosystems (Forsyth, Van Wilgen \& Schonegevel 2007). A set of preliminary thresholds had been developed by Van Wilgen \& Scott (2001), and these were used as a basis for the development of operational and ecosystem thresholds for the TMNP (Table 2).

An analysis of recent fire records revealed that the threshold regarding the area of fynbos $(36.4 \%)$ in the age class of 4-6 years was $16.4 \%$ greater than the desired $20 \%$ upper threshold (Forsyth et al. 2007; Forsyth \& Van Wilgen 2008), mainly because of a large unplanned fire in January 2000. Slower-growing serotinous Proteaceae in the area were therefore vulnerable to subsequent unplanned fires, should they occur. As a result of the threshold being exceeded, it was proposed that the vegetation should not be burnt for at least a further 4 years, and that the management emphasis in this area should be on protecting the vegetation from fire and ensuring a rapid response to limit the extent thereof in the event of an unplanned fire. Fire size distributions were also found to have exceeded thresholds. Large fires accounted for only approximately $45 \%$ of the area of all fires. In addition, a few large fires in January 2000 exceeded the upper threshold of 2000 ha. The remaining (ecosystem) thresholds in Table 2 have not yet been assessed, mainly because monitoring programmes to gather the necessary data are not yet in place.

\section{Bontebok National Park}

The BNP is a small protected area (Table 1), originally proclaimed to protect the rare bontebok (Damaliscus pygargus pygargus). Vegetation types within the park are also rare and threatened (Kraaij 2011), and the park's managers have long been faced with the dilemma of reconciling the need for short-interval fires that promote grazing for bontebok, with that for longer-interval fires to maintain plant diversity (Kraaij 2010). In the 1970s a short-interval burning programme was introduced to stimulate grazing for bontebok. Under this programme renosterveld and fynbos vegetation were burnt at intervals of 4 and 12 years, respectively. In response to the increasing need to conserve the vegetation, prescribed burning schedules were changed in 2004, and the interval between fires was extended to not less than 8 years in renosterveld vegetation and 16 years in fynbos. As a result, mean fire return periods increased from 6.7 to 10.9 years (Kraaij 2010). In order to monitor and improve fire management in the BNP a preliminary set of thresholds for fire (in terms of frequency, season and size distribution) has been developed, in line with those used in the TMNP (Table 3). Some of the thresholds used in the BNP were adopted from the TMNP set, and would apply, for example, to surviving populations of obligate reseeding Protea repens shrubs. Furthermore, thresholds were designed to address the effects of interacting fire and grazing (Kraaij \& Novellie 2010; Novellie \& Kraaij 2010) on the vegetation.

\section{Assessment of progress}

Despite the attempted introduction of adaptive approaches to fire management, our understanding has not yet been noticeably advanced, at least in the TMNP. In the case of the BNP, it is too early to expect that progress should have been made. In reality, the attempt to introduce an adaptive approach to fire management in the TMNP has suffered from a number of shortcomings, including the following:

- a holistic adaptive management approach was not followed in these cases, in that that there was no formulation of a desired state and a hierarchy of objectives, agreed to by all stakeholders, that would have provided the purpose and focus of management

- the purpose and use of thresholds were not universally well understood by the TMNP's managers

- several important problems relating to fire management in the TMNP were not addressed in the formulation of operational and ecosystem thresholds. These problems relate to how to deal with a critical public (including gaining consensus within a fire protection association whose members did not share biodiversity goals), how to use scarce resources to ensure that both safety and ecosystem goals are met, and how to deal effectively with invasive alien plants.

Because of these shortcomings, there has been little real buyin regarding adaptive management approaches, very little monitoring, and almost no assessment. In the case of the $\mathrm{BNP}$, the thresholds presented here are recent (developed in 2008) and have not yet been assessed. It would appear, therefore, that the well-intentioned attempt to introduce an element of adaptive management, addressing fire alone, has not yet delivered any tangible benefits. In order to make progress, attention to the development of a shared vision and desired future state, and the formulation of a hierarchy of objectives, agreed to by all stakeholders, will be required. 
TABLE 2: Proposed thresholds of potential concern relating to fire management in the Table Mountain National Park.

Measure

Thresholds

\begin{tabular}{|c|c|}
\hline Area of potential concern & Reason for concern \\
\hline & Operational threshol \\
\hline $\begin{array}{l}\text { Post-fire age distribution will be } \\
\text { skewed or uneven. }\end{array}$ & $\begin{array}{l}\text { An unequal distribution of age classes will not provide } \\
\text { sufficient habitat for a full range of species requiring } \\
\text { access to vegetation of different ages, and will not allow } \\
\text { for manageable amounts of vegetation to be scheduled for } \\
\text { prescribed burning each year. }\end{array}$ \\
\hline $\begin{array}{l}\text { Large areas will go without fire for } \\
\text { too long. } \dagger\end{array}$ & $\begin{array}{l}\text { Fires in older vegetation will lead to poor post-fire } \\
\text { reproduction in groups of plants prone to senescence } \\
\text { (e.g. serotinous Proteaceae). }\end{array}$ \\
\hline $\begin{array}{l}\text { Large areas will burn too } \\
\text { frequently. }\end{array}$ & $\begin{array}{l}\text { Fires in populations of immature obligate re-seeding plants } \\
\text { will lead to poor post-fire regeneration, population declines } \\
\text { and local extinction. }\end{array}$ \\
\hline \multirow[t]{3}{*}{$\begin{array}{l}\text { Fires will occur in ecologically } \\
\text { unacceptable seasons. }\end{array}$} & $\begin{array}{l}\text { Spring and winter fires result in poor regeneration of } \\
\text { serotinous Proteaceae. }\end{array}$ \\
\hline & Spring fires are detrimental to nesting birds. \\
\hline & $\begin{array}{l}\text { In general, burning at times other than the hot, dry time of } \\
\text { the year will lead to detrimental effects, as the biota would } \\
\text { not have evolved under such regimes. }\end{array}$ \\
\hline
\end{tabular}

$-$

$\begin{array}{ll} & \\ & \\ \begin{array}{l}\text { Instead of a similar area being } \\ \text { burnt each year, a few large fires, } \\ \text { or, alternately, a large number of } \\ \text { small fires could occur. }\end{array} & \begin{array}{l}\text { Too many small fires will be difficult and costly to manage. } \\ \text { be greater, with many small fires. }\end{array} \\ & \begin{array}{l}\text { Very large fires (>10\% of the area of the park) will upset the } \\ \text { desired goal of maintaining an even distribution of post-fire } \\ \text { ages. }\end{array}\end{array}$

Proportion of area in 10 equal post-fire age classes between 0 to 30 years.
Proportion of the area $>30$ years post-fire.

Fire return intervals assessed over the past 30 years.

\section{The proportion of the area that} burns in summer (November January inclusive) over the last 15 years. burns in autumn (February - April inclusive) over the last 15 years.

The proportion of the area that burns in winter (May - August inclusive) over the last 15 years.

The proportion of the area that burns in spring (September and October) over the last 15 years.

The distribution of areas of all individual fires over the past 15 years. Adjoining fires that burn in the same season of the same year
The proportion of the area that should be counted as one fire.
The proportion of area in each age class should be $>5 \%$ and $<20 \%$. post-fire should be $<20 \%$.

Fire return intervals should not be $<10$ years on $>20 \%$ of the area.

Should be $>40 \%$.

Should be $>40 \%$.

Should be $<10 \%$.

Should be $<10 \%$.

The proportion area burnt in fires $>1000$ ha should be $>75 \%$.

Single fires should not exceed 2000 ha.

\section{Ecosystem thresholds}

\section{Insufficient individuals in} populations of serotinous Proteaceae will reach maturity and set seed prior to fire.
Fires that occur in relatively immature populations will lead to $\mathrm{Pr}$ population declines or local extinction.

Fires that occur in senescent populations will lead to population declines or local extinction.

populations of serotinous

Proteaceae will reach senescence

Post-fire recruitment in populations of serotinous

Proteaceae could be inadequate replace pre-fire populations. $\dagger$

Fires in ecologically disadvantageous conditions (either season, post-fire age, drought or exposure to high levels of

seed predation) could lead to failure of adequate populations to establish after fire, leading to population declines of local extinction. prior to fire.
Proportion of individual populations At least $50 \%$ of individuals in a that have flowered for $>3$ successive seasons. monitored population should have seasons before a fire.

Proportion of individual populations No more than $25 \%$ of individuals that show advanced signs of in a monitored population should senescence. have advanced signs of senescence before a fire.

The ratio of seedlings to parent Seedling to parent ratios should plants measured 3 years after a fire. be $>2$. flowered for at least 3 successive

\section{Rare or threatened species may be The existence of disadvantageous fire regimes could lead to negatively affected by fires. $\dagger$}

Population declines of $>25 \%$ in inter-fire periods.

Post-fire population sizes should be at least $75 \%$ of pre-fire population levels.

Thresholds are divided into operational thresholds (for the guidance of managers) and ecosystem thresholds (that would be assessed by scientists and used to adjust operational thresholds if necessary).

$\dagger$, Indicates thresholds which also apply to the Bontebok National Park (see Table 3).

This would provide a defendable purpose and clear focus for management for achieving the desired state. Should this be done, fire management issues will be more appropriately embedded within an agreed hierarchy of objectives, and should lead to improvements in fire management over time.

\section{Discussion Making use of modelling}

The operational thresholds proposed for TMNP and BNP in terms of fire return intervals, season and size, are first 
approximations, based on current understanding of what constitutes a fire regime under which biodiversity can be conserved. However, whether, under what circumstances, or how often these thresholds are likely to be exceeded is not clearly understood. Issues of scale are also important here. In the KNP, the area is probably large enough for fire patterns to remain within thresholds on average. However, a single fire could cover the whole of the BNP, resulting in most of the thresholds being exceeded. The appropriate management responses to such scenarios have not yet been thought through. The modern and historic fire regimes in fynbos and savanna ecosystems are well understood (Forsyth \& Van Wilgen 2008; Seydack et al. 2007; Van Wilgen et al. 2000; Van Wilgen et al. 2010), and a range of plausible scenarios could be formulated and modelled relatively easily. In this way, the frequency with which thresholds are likely to be exceeded in individual protected areas could be rapidly generated. This could lead either to the formulation of appropriate responses in advance, or to the delimitation of more appropriate thresholds. Either way, this approach would lead to more rapid learning, and should be considered.

\section{Linking fire to conservation outcomes}

Whether or not adaptive fire management (as practised by SANParks) is having the desired effect of conserving biodiversity is an important question. The adoption of thresholds in terms of fire patterns may appear at first glance to imply that the fire patterns themselves are the desired outcome. In the KNP, the overall goal for ecosystem management in the objectives hierarchy is 'to understand and manage the KNP as part of the lowveld savanna ... in

TABLE 3: Proposed thresholds of potential concern relating to fire management and fire-herbivory interactions in the Bontebok National Park.

\begin{tabular}{|c|c|c|c|}
\hline Area of potential concern & Reason for concern & Measure & Thresholds \\
\hline \multicolumn{4}{|c|}{ Operational thresholds } \\
\hline $\begin{array}{l}\text { Either too much or too little of the } \\
\text { park may burn in a single year. }\end{array}$ & $\begin{array}{l}\text { Over-utilisation by herbivores of a small burnt area, resulting } \\
\text { in damage to the vegetation. } \\
\text { Lack of fuel available for burning in subsequent years (if } \\
\text { too large an area burns), leading to a shortage of forage for } \\
\text { bontebok, and absence of a seed source for dispersal. }\end{array}$ & $\begin{array}{l}\text { Proportion of the area of the park } \\
\text { that burns in a single year. }\end{array}$ & Should be $>10 \%$ and $<33 \%$. \\
\hline $\begin{array}{l}\text { Large areas will burn when the } \\
\text { vegetation is immature. }\end{array}$ & Failure or poor recruitment of reseeding plants after fire. & $\begin{array}{l}\text { Proportion of the area per } \\
\text { vegetation type that burnt during } \\
\text { the past } 5 \text { years while immature. }\end{array}$ & $\begin{array}{l}\text { Less than } 10 \% \text { of, }(1) \text { renosterveld/ } \\
\text { asteraceous fynbos should burn at } \\
\text { a post-fire age of }<8 \text { years and ( } 2 \text { ) } \\
\text { proteoid fynbos should burn at a } \\
\text { post-fire age of }<12 \text { years. }\end{array}$ \\
\hline $\begin{array}{l}\text { Post-fire age distribution will be } \\
\text { highly skewed or uneven. }\end{array}$ & $\begin{array}{l}\text { An unequal distribution of age classes will not provide } \\
\text { sufficient habitat for a full range of species (particularly large } \\
\text { herbivores) requiring access to vegetation of different ages. }\end{array}$ & $\begin{array}{l}\text { Proportion of the area in three age } \\
\text { classes ( } 0-2 \text { years, } 3-5 \text { years, and } \geq 6 \\
\text { years) for renosterveld/asteraceous } \\
\text { fynbos, and three age classes ( } 0-6 \\
\text { years, } 7-12 \text { years, and }>12 \text { years) for } \\
\text { proteoid fynbos. }\end{array}$ & $\begin{array}{l}\text { The proportion of area in each age } \\
\text { class should be }>25 \% \text { and }<50 \%\end{array}$ \\
\hline $\begin{array}{l}\text { Fires will occur in ecologically } \\
\text { unacceptable seasons. }\end{array}$ & $\begin{array}{l}\text { Spring and winter fires result in poor regeneration of } \\
\text { serotinous Proteaceae. }\end{array}$ & $\begin{array}{l}\text { The proportion of the area that } \\
\text { burnt outside of the prescribed } \\
\text { season (i.e. December-April) during } \\
\text { the past five years. }\end{array}$ & Should be $<25 \%$. \\
\hline
\end{tabular}

Spring fires are detrimental to nesting birds.

In general, burning at times other than the hot, dry time of the year will lead to detrimental effects, as the biota would not have evolved under such regimes.

Ecosystem thresholds

\begin{tabular}{|c|c|c|c|}
\hline $\begin{array}{l}\text { Decrease in forage value of } \\
\text { vegetation due to under- or over- } \\
\text { utilisation. }\end{array}$ & $\begin{array}{l}\text { Infrequent burning and low levels of grazing pressure could } \\
\text { lead to a decrease in forage value. } \\
\text { Heavy grazing of recently burnt vegetation could lead to a } \\
\text { decrease in forage value. }\end{array}$ & $\begin{array}{l}\text { Cover, extent of defoliation and } \\
\text { inflorescence production in an } \\
\text { indicator grass species (Themeda } \\
\text { triandra). }\end{array}$ & $\begin{array}{l}\text { (1) Mean defoliation (\% of shoots } \\
\text { severed) in } \leq 5 \text {-year-old vegetation } \\
\text { should be }>25 \% \text { and }<75 \% \text {. } \\
\text { (2) }>10 \% \text { of plants in } \leq 5 \text {-year- } \\
\text { old vegetation should have } \\
\text { inflorescences. } \\
\text { (3) A decline in the cover of } \\
\text { Themeda triandra of }>10 \% \text { per year } \\
\text { sustained over } 3 \text { years or more. }\end{array}$ \\
\hline $\begin{array}{l}\text { Overgrazing could lead to loss of } \\
\text { vegetation diversity. }\end{array}$ & $\begin{array}{l}\text { Short-grass grazers (e.g. bontebok) promote the formation of } \\
\text { grazing lawns (Cynodon dactylon), particularly when utilising } \\
\text { recently burnt vegetation. The spread of grazing lawns could } \\
\text { reduce vegetation diversity. }\end{array}$ & $\begin{array}{l}\text { Change in the surface area of grazing } \\
\text { lawns. }\end{array}$ & $\begin{array}{l}\text { An increase in the grazing lawn } \\
\text { surface area of }>25 \% \text { relative to } \\
\text { baseline survey. }\end{array}$ \\
\hline
\end{tabular}


such a manner as to conserve and restore its varied natural structure, function and composition over time and space ... through an approach integrating the different scales and types of objectives'. This goal, ultimately, was sub-divided into 369 sub-objectives (13 for atmosphere, 116 for water, 204 for terrestrial, 30 for alien species, and 6 for threatened biota, respectively), only 6 of which relate to fire. The outcomes of fire management interventions, ultimately, will manifest themselves in terms of vegetation structure, function and composition, which are monitored in terms of non-fire thresholds set to address the other sub-objectives. It has not yet been possible to make any definite links between fire interventions and conservation (biodiversity) outcomes in the KNP. In a critical assessment of adaptive management in the KNP, Van Wilgen and Biggs (2010) concluded that 'because the conservation outcomes of management shifts will only manifest themselves in the longer term, the relative success of adaptive management should be measured by the degree to which management has been refocused onto priority issues, and by the rate at which new understanding is generated'.

Because of the difficulty of making links between fire interventions and biodiversity outcomes, the thresholds set for fire regimes are seen by managers as operational thresholds; that is, they guide managers towards targets that can be relatively easily understood. Although the difference between operational and ecosystem thresholds was never framed as such in the KNP, the distinction has been made explicit in the thresholds proposed for the TMNP and the BNP (Tables 2 and 3). Ultimately, however, the links need to be made between fire patterns and the ecological outcomes as embodied in the ecosystem thresholds, and this remains a major future challenge.

\section{Acknowledgements}

We thank the CSIR, the National Research Foundation, South African National Parks and the DST/NRF Centre for Invasion Biology for supporting the production of this paper. Angela Gaylard and Philip Prins commented on an earlier version of this paper. This paper was extensively revised following constructive criticism from two anonymous reviewers.

\section{References}

Bands, D.P., 1977, 'Prescribed burning in Cape Fynbos' in H.A. Mooney \& C.E. Conrad (eds.), Proceedings of the symposium on the environmental consequences of fire and fuel management in mediterranean ecosystems, Palo Alto, California, 01-5 August, 1977, pp. 245-256, General Technical Report WO-3, USDA Forest Service.

Biggs, H.C. \& Potgieter, A.L.F., 1999, 'Overview of the fire management policy of the Kruger National Park', Koedoe 42, 101-110.

Biggs, H.C. \& Rogers, K.H., 2003, 'An adaptive system to link science, monitoring and management in practice' in J.T. du Toit, K.H. Rogers, H.C. Biggs (eds.), The Kruger experience: Ecology and management of savanna heterogeneity, pp. 59-80, Island Press, New York.

Bond, W.J., 1997, 'Fire', in R.M. Cowling, D.M. Richardson \& S.M Pierce (eds.), Vegetation of southern Africa, pp. 421-446, Cambridge University Press, Cambridge.

Bond, W.J. \& Archibald, S., 2003, 'Confronting complexity: fire policy choices in South African savanna parks', International Journal of Wildland Fire 12, 381-389. doi:10.1071/WF03024

Bond, W.J., Woodward, F.I. \& Midgley, G.F., 2003, 'The importance of low atmospheric $\mathrm{CO} 2$ and fire in promoting the spread of grasslands and savannas', Global Change Biology 9, 973-982. doi:10.1046/j.1365-2486.2003.00577.x
Brockett, B.H., Biggs, H.C. \& Van Wilgen, B.W., 2001, 'A patch mosaic burning system for conservation areas in southern Africa', International Journal of Wildland Fire 10, 169-183. doi:10.1071/WF01024

Brynard, A.M., 1971, 'Controlled burning in the Kruger National Park: History and development of the range burning policy', Proceedings: Tall Timbers Fire Ecology Conference, Tallahassee, Florida, 10-13 April, 1971, 219-231.

Eckhardt, H.C., Van Wilgen, B.W. \& Biggs, H.C., 2000, 'Trends in woody vegetation cover in the Kruger National Park, South Africa, between 1940 and 1998', African Journal of Ecology 38, 108-115. doi:10.1046/j.1365-2028.2000.00217.x

Edkins, M.T., Kruger, L.M., Harris, K. \& Midgley, J.J., 2007, 'Baobabs and elephants in Kruger National Park: Nowhere to hide', African Journal of Ecology 38, 108-115.

Edwards, P.J., 1984, 'The use of fire and a management tool', in P. de V. Booysen \& N.M. Tainton (eds.), Ecological effects of fire in South African ecosystem, pp. 349362, Springer, Berlin.

Forsyth, G.G. \& Bridgett, J., 2004, Table Mountain National Park Fire Management Plan, Report ENV-S-C-2004-043, CSIR, Stellenbosch.

Forsyth, G.G. \& Van Wilgen, B.W., 2008, 'The recent fire history of the Table Mountain National Park, and implications for fire management', Koedoe 50, 3-9.

Forsyth, G.G., Van Wilgen, B.W., Ruddock, G., Nel, J.L., Le Maitre, D.C., Smith, N., et al., 2000, A fire management plan for the Cape Peninsula National Park, Report ENV-S-C 2000-111, CSIR, Stellenbosch.

Forsyth, G.G., Van Wilgen, B.W. \& Schonegevel, L.Y., 2007, An assessment of the current fire situation, proposed fire monitoring and recommendations for future fire management activities in the Table Mountain National Park, Report CSIR/ NRE/ECO/ER/2007/0056/C, CSIR, Stellenbosch.

Gill, A.M. \& Allan, G., 2008, 'Large fires, fire effects and the fire regime concept', International Journal of Wildland Fire 17, 688-695. doi:10.1071/WF07145

Higgins, S.I., Bond, W.J. \& Trollope, W.S.W., 2000, 'Fire, resprouting and variability: A recipe for grass-tree coexistence in savanna', Journal of Ecology 88, 213-229. doi:10.1046/j.1365-2745.2000.00435.x

Holling, C.S. \& Meffe, G.K., 1996, 'Command and control and the pathology of natural resource management', Conservation Biology 10, 328-337. doi:10.1046/j.1523-1739.1996.10020328.x

Holmes, P.M., Richardson, D.M., Van Wilgen, B.W. \& Gelderblom, C., 2000, 'The recovery of South African fynbos vegetation following alien tree clearing and fire: Implications for restoration', Austral Ecology 25, 631-639. doi:10.1046/j.1442-9993.2000.01063.x, doi:10.1111/j.1442-9993.2000.tb00069.x

Joubert, S., 2007, The Kruger National Park: A history, 3 vols., High Branching, Johannesburg.

Kraaij, T., 2010, 'Changing the fire management regime in the renosterveld and lowland fynbos of the Bontebok National Park', South African Journal of Botany 76, 550-557. doi:10.1016/j.sajb.2010.04.008

Kraaij, T., 2011, 'The flora of the Bontebok National Park in regional perspective', South African Journal of Botany. doi:10.1016/j.sajb.2010.09.013

Kraaij, T. \& Novellie, P.A., 2010, 'Habitat selection by large herbivores in relation to fire at the Bontebok National Park (1974-2009): The effects of management changes', African Journal of Range and Forage Science 27(1), 21-27. doi:10.2989/10220111003703450

Kraaij, T. \& Ward, D., 2006, 'Effects of rain, nitrogen, fire and grazing on tree recruitment and early survival in bush-encroached savanna, South Africa', Plant Ecology 186, 235-246. doi:10.1007/s11258-006-9125-4

Mentis, M.T. \& Bailey, A.W., 1990, 'Changing perceptions of fire management in savanna parks', Journal of the Grassland Society of Southern Africa 7, 81-85.

Novellie, P. \& Kraaij, T., 2010, 'Evaluation of Themeda triandra as an indicator for monitoring the effects of grazing and fire in the Bontebok National Park', Koedoe 52(1), 49-53.

Phillips, J.F.V., 1930, 'Fire: Its influence on biotic communities and physical factors in South and East Africa', South African Journal of Science 27, 352-367.

Resilience Alliance, 2010, Adaptive management, viewed 03 June 2009, from http:// www.resalliance.org/600.php

Rogers, K.H., 2003, 'Adopting a heterogeneity paradigm: Implications for management of protected savannas' in J. du Toit, K.H. Rogers \& H.C. Biggs (eds.), The Kruger experience: Ecology and management of savanna heterogeneity, pp. 468-488, Island Press, New York.

Roques, K.G., O'Connor, T.G. \& Watkinson, A.R., 2001, 'Dynamics of shrub encroachment in an African savanna: relative influences of fire, herbivory, rainfall and density dependence', Journal of Applied Ecology 38, 268-280. doi:10.1046/j.1365-2664.2001.00567.x

SANParks, 2008, A framework for developing and implementing management plans for South African National Parks, Conservation Services Division, South African National Parks, Pretoria, $24 \mathrm{pp}$.

Seydack, A.H.W., Bekker, S.J. \& Marshall, A.H., 2007, 'Shrubland fire regime scenarios in the Swartberg Mountain Range, South Africa: Implications for fire management', International Journal of Wildland Fire 16, 81-95. doi:10.1071/WF06015

Trollope, W.S.W., 1998, Effect and use of fire in the savanna areas of southern Africa, Department of Livestock and Pasture Science, University of Fort Hare.

Van der Schijff, H.P., 1958, 'Inleidende verslag oor veldbrandnavorsing in die Nationale Krugerwildtuin [Preliminary report on wildfire research in the Kruger National Park]', Koedoe 1, 60-93. 
Van Wilgen, B.W., 2009a, 'The evolution of fire and invasive alien plant management practices in fynbos', South African Journal of Science 105, 335-342.

Van Wilgen, B.W., 2009b, 'The evolution of fire management practices in savanna protected areas in South Africa', South African Journal of Science 105, 343-349.

Van Wilgen, B.W. \& Biggs, H.C., 2010, 'A critical assessment of adaptive ecosystem management in a large savanna protected area in South Africa', Biological management in a large savanna protected ar
Conservation. doi:10.1016/j.biocon.2010.05.006.

Van Wilgen, B.W., Biggs, H.C., O'Regan, S. \& Mare, N., 2000, 'A fire history of the savanna ecosystems in the Kruger National Park, South Africa between 1941 and 1996 ', South African Journal of Science 96, 167-178.

Van Wilgen, B.W., Biggs, H.C. \& Potgieter, A.L.F., 1998, 'Fire management and research in the Kruger National Park, with suggestions on the detection of thresholds of potential concern', Koedoe 41, 69-87.

Van Wilgen, B.W., Bond, W.J. \& Richardson, D.M., 1992, 'Ecosystem management', in R.M. Cowling (ed.), The ecology of fynbos: Nutrients, fire and diversity, pp. 345-371, Oxford University Press, Cape Town.

Van Wilgen, B.W., Forsyth, G.G., De Klerk, H., Das, S., Khuluse, S. \& Schmitz, P., 2010, 'Fire management in Mediterranean-climate shrublands: A case study from the Cape fynbos, South Africa', Journal of Applied Ecology 47, 631-638. doi:10.1111/j.1365-2664.2010.01800.x

Van Wilgen, B.W., Govender, N. \& Biggs, H.C., 2007, 'The contribution of fire research to fire management: A critical review of a long-term experiment in the Kruger National Park, South Africa', International Journal of Wildland Fire 16, 519-530. doi:10.1071/WF06115
Van Wilgen, B.W., Govender, N., Biggs, H.C., Ntsala, D. \& Funda, X.N., 2004 'Response of savanna fire regimes to changing fire management policies in a large African national park', Conservation Biology 18, 1533-1540. doi:10.1111/j.1523-1739.2004.00362.x

Van Wilgen, B.W., Govender, N. \& MacFadyen, S., 2008, 'An assessment of the implementation and outcomes of recent changes to the fire management of the Kruger National Park', Koedoe 50, 22-31.

Van Wilgen, B.W., Richardson, D.M. \& Seydack, A., 1994, 'Managing fynbos for biodiversity: constraints and options in a fire-prone environment', South African Journal of Science 90, 322-329.

Van Wilgen, B.W. \& Scott, D.F., 2001, 'Managing fires on the Cape Peninsula: Dealing with the inevitable', Journal of Mediterranean Ecology 2, 197-208.

Venter, F.J., Naiman, R.J., Biggs, H.C. \& Pienaar, D.J., 2008, 'The evolution of conservation management philosophy: Science, environmental change and social adjustments in Kruger National Park', Ecosystems 11, 173-192. doi:10.1007/s10021-007-9116-x

Walters, C.J. \& Green, R., 1997, 'Valuation of experimental management options for ecological systems', Journal of Wildlife Management 61, 987-1006. doi:10.2307/3802096

Wilhere, G.F., 2002, 'Adaptive management in habitat conservation plans', Conservation Biology 16, 20-29. doi:10.1046/j.1523-1739.2002.00350.x 